\title{
Optimization of Novel Sphere Sandwich Structure for Impact Requirements
}

\author{
Meethaq M. Abed ${ }^{1 *}$, Mohammed H. Al-maammori ${ }^{2}$ \\ ${ }^{1}$ Technical Institute of Karbala, Al-Furat Al-Awsat Technical University, Karbala 56001, Iraq \\ ${ }^{2}$ College of Engineering Materials, University of Babylon, Babil 51001, Iraq
}

Corresponding Author Email: inkr.mth@atu.edu.iq

https://doi.org/10.18280/acsm.440403

Received: 5 March 2020

Accepted: 12 July 2020

\section{Keywords:}

carving wax, Sphere Sandwich Structure, lightweight materials, RSM-optimization

\begin{abstract}
Sphere Sandwich Structures (SSS) are a new structure which may have the potentials to provide the energy absorption as compared with monolithic specimen material. By using innovation carving wax method, fifteen specimens have been prepared according to RSM optimize method and it machined by CNC-3axis machine with sphere end screw. Three factors sphere diameter(D), distance between spheres(X) and skin thickness(K) have been studied. The impact test has been achieved by Izod test to calculate specific fracture toughness. The results show the sample 642 has the highest specific fracture toughness value with an improvement of $300 \%$ compared with the monolithic sample. The optimal value of this test is $35.37 \mathrm{MPa} \mathrm{m}{ }^{0.5} \mathrm{~g}^{-1}$ of the sample 682 (diameter $=6$, distance between spheres $=8$, skin thickness $=2 \mathrm{~mm}$ ) with $10 \%$ error when compared with practice result at the same geometry. According to ANOVA analysis, the diameter of sphere(D) has greatest effect than other factors and then skin thickness $(\mathrm{K})$.
\end{abstract}

\section{INTRODUCTION}

There are many important factors when plastic and composite materials used as a component in automobile bodies, these are mechanical performance, impact, temperature, performance and durability in service [1]. Impact is very important factor in automotive bumper system to absorb impact energy which generated during accidents [2-4]. Every day accidents in cars are happening, so 1.2 million people dead and hundreds of 10 million wounded each year according to the statistics. To improve the safety of automobiles during accidents, automotive bumper system is one of the key systems in passenger cars [5]. The polymeric based composite materials were the first material that introduced in a new technology of material for its excellent properties, which offer low weight, high impact energy absorption, high specific stiffness, high specific strength, producing complex shapes, and high corrosion resistance. In addition, its perfect property to reduce the weight which tend to fuel reduction $[6,7]$.

According to reinforcement principles in materials, there are two types of reinforcement: the first by adding additives (fibers and particles) such as composite materials and the second by shapes such as I-section beam [8]. A new innovation directed to use the shape reinforcement to get much properties such as stiffness-weight ratio, strength- weight ratio and energy absorption. The spherical shape was the first shape which used to disperse impact energy and may be Andrews [9] was the first research who gave a detail description of sphere structure at three dimensions in his multi-layer composite armor design. This study showed that the primary advantage of sphere structure is dispersion of associated energy with ballistic projectile toward the perimeter of the layer of sphere structure rather than steering all of energy normal through the protecting layers.

Fu et al. [10] innovated Unit Cell of Square Based Pyramid
(SBPUC) to describe 3D-arrangemnt of a new sandwich sphere structure. In their research, they studied a design of numerical simulation in three models and concluded that at least $11.6 \%$ of impact kinetic energy can absorb by the new structure than by monolithic plate.

Another research owned to $\mathrm{Fu}$ et al. [11] studied the diameters relation between incoming projectile and the spheres of sandwich core, initial impact velocity of the projectile and arrangement of the spheres. This research showed that diameter of spheres at different layers in one sandwich core should either decrease or increase monotonically and them exists critical impacting speed.

The important research by Pandyaraj et al. [12] innovated a novel sandwich structure with spherically core. They experimentally investigated the compression properties for different models Regular, Inverted, Interlock, Stagger with chopped and woven glass fibers. They concluded the interlock design have higher value of strength and compression than other designs and glass chopped specimens have higher value of strength and compression than Glass woven specimens at all designs.

Lam et al. [13] studied the mechanism of deformation and the energy absorption characteristics of the cells of flat-topped grid-dome cellular composites which fabricate from nonwoven PET fabric reinforcement with polypropylene (PP) matrix. Quasi-static axial compression and impact tests achieved on it to formulate cell deformation modes. The concluded the analytical expressions have good agreement between with results.

Yu et al. [14] studied three grid-domed textile composites under quasi-static compression and impact condition. The concluded the grid-domed cellular structure have the highest specific energy absorbing than other shapes. Also, they concluded good agreement between experimental and prediction results. 
The aim of this study is to design novel lightweight sphere sandwich structure (SSS) and optimize its three variables the diameter of sphere(D), distance between sphere(X) and skin thickness(K). This SSS manufactured without using any adhesive between skins, however, the spheres are self-bonded with skins. The process used to fabricate SSS is innovation method and based on carving wax. Shortly, the spheres are machined on the carving wax panel by CNC-3axis machine with end sphere screw to get hollow spheres which distributed according to experimental design method (RSM)and then the fluid resin (unsaturated polyester resin) has poured inside it. After the casting has been finished, the model immersed in a boiled water bath to melt the wax, which comes out from the polyester sample by the gravity force, and the result will be formed a model of self-adhering solid balls between two skins and as a form of a sandwich panel.

Surface response methodology RSM (Box-Behenkin method) is used to get optimization values and modeling parameters. In Box-Behenkin method 3 variables and 3 levels for each variable have been used so the runs number are 15 . Here the response is specific fracture toughness.

\section{MATERIALS AND METHODOLOGY}

\subsection{Design of experiments (DOE)}

Design of experiments had accomplished by Minitab17 according to Box-Behnken method. In this method, there are three variables(factors) $\mathrm{D}, \mathrm{X}$ and $\mathrm{K}$. and three levels in each factor as Table 1. Figure 1 shows the variables of sphere sandwich structure specimen.

So, the number of runs is 15 experiment. The runs and codes of specimens are shown in Table 2.

Table 1. DOE by Box-Behnken method

\begin{tabular}{lccc}
\hline \multicolumn{4}{c}{ Box - Behenkin Method } \\
\hline Factors & $\begin{array}{c}\text { Sphere } \\
\text { Diameter(D) }\end{array}$ & $\begin{array}{c}\text { Distance Between } \\
\text { Spheres(X) }\end{array}$ & $\begin{array}{c}\text { Skin } \\
\text { Thickness(K) }\end{array}$ \\
\hline Levels & 6 & 0 & 2 \\
& 12 & 4 & 3 \\
& 18 & 8 & 4 \\
\hline
\end{tabular}

Table 2. Runs by Box-Behnken Method

\begin{tabular}{ccccc}
\hline Code & $\begin{array}{c}\text { Skin } \\
\text { Thickness(K) } \\
\text { mm }\end{array}$ & $\begin{array}{c}\text { Distance } \\
\text { between } \\
\text { spheres } \\
(\mathbf{X}) \mathbf{m m}\end{array}$ & $\begin{array}{c}\text { Sphere } \\
\text { Diameter } \\
(\mathbf{D})\end{array}$ & No \\
$\mathbf{\text { mm }}$ & \\
\hline 1 & 6 & 4 & 2 & 642 \\
2 & 6 & 0 & 3 & 603 \\
3 & 6 & 8 & 3 & 683 \\
4 & 6 & 4 & 4 & 644 \\
5 & 12 & 0 & 2 & 1202 \\
7 & 12 & 4 & 3 & 1243 \\
8 & 12 & 4 & 3 & 1243 \\
9 & 12 & 4 & 3 & 1243 \\
10 & 12 & 0 & 4 & 1204 \\
11 & 12 & 8 & 4 & 1284 \\
12 & 18 & 4 & 2 & 1842 \\
13 & 18 & 0 & 3 & 1803 \\
14 & 18 & 8 & 3 & 1883 \\
15 & 18 & 4 & 4 & 1844 \\
\hline
\end{tabular}

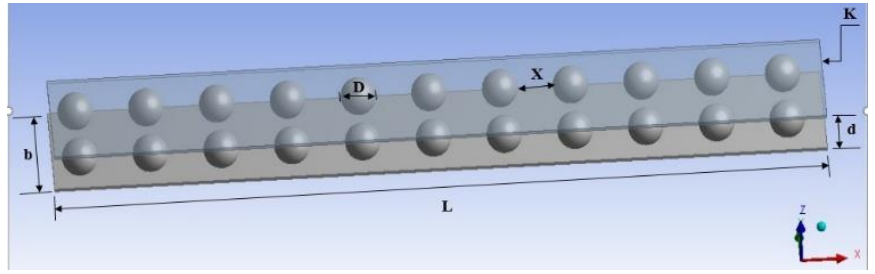

Figure 1. Sphere Sandwich Structure specimen

\subsection{Fabrication of specimen}

The SSS was made by innovative method as detailed by the following steps:

\subsubsection{Shape design of wax panel}

Thickness of wax panel was calculated according to Eq. (1) as Table 3:

$$
\mathrm{T}_{\mathrm{wax} \text { panel }}=\text { Skin Thickness }(\mathrm{K})+\operatorname{Radius}(\mathrm{R})
$$

Table 3. Thickness of wax panel

\begin{tabular}{ccc}
\hline No & Code & $\begin{array}{c}\mathrm{T}_{\text {wax }} \\
\mathrm{mm}\end{array}$ \\
\hline 1 & 642 & 5 \\
2 & 603 & 6 \\
3 & 683 & 6 \\
4 & 644 & 7 \\
5 & 1202 & 8 \\
6 & 1282 & 8 \\
7 & 1243 & 9 \\
8 & 1243 & 9 \\
9 & 1243 & 9 \\
10 & 1204 & 10 \\
11 & 1284 & 10 \\
12 & 1841 & 11 \\
13 & 1803 & 12 \\
14 & 1883 & 12 \\
15 & 1844 & 13 \\
\hline
\end{tabular}

\subsubsection{Graphics design}

In this step, it was used ArtCAM graphics software to draw specimens as Figure 2 and then exporting to CNC-Router machine as (Tap) extent (G-code language). It had divided specimen graphic to parts. Each part would achieve function such as edge cutting, sphere drilling and area clearance etc., as Figure 3.

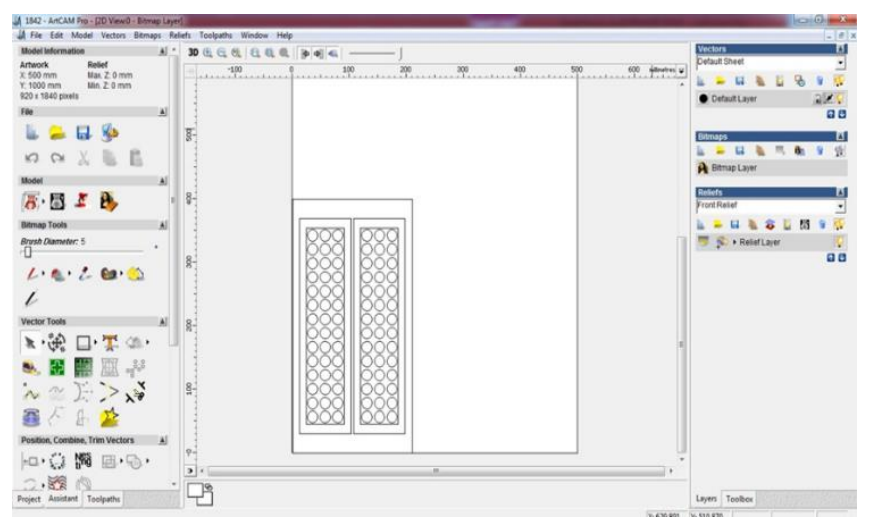

Figure 2. Graphics of specimen by ArtCAM software 


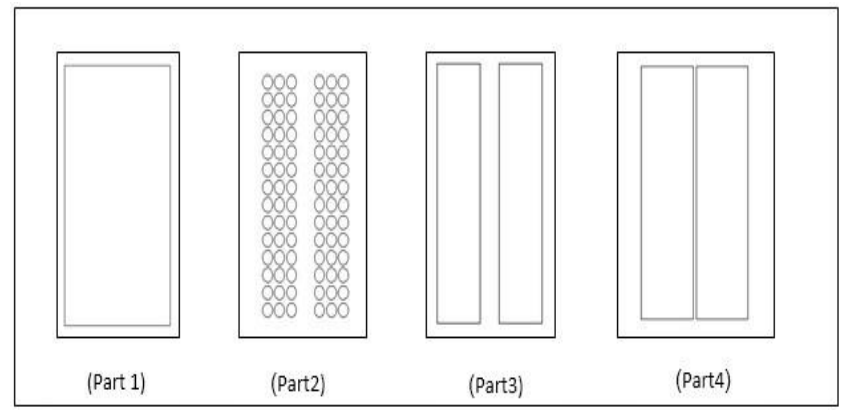

Figure 3. Four parts for export to CNC-Machine

\subsubsection{Execution step}

In this step, it had been executed (Tap) files by CNC-Router machine as follow steps, see in Figure 4:

(1)-fixing of wood panel and machining zero level on it.

(2)-fixing of wax panel at $90^{\circ}$ with respect to $\mathrm{z}$-axis (cutting axis).

(3)-machining of the first face to make spheres cavities.

$(4,5)$ - machining of the second face to make skins cavities.

(6)-cutting of edges to get two half wax panel to form at the same time completed mold.

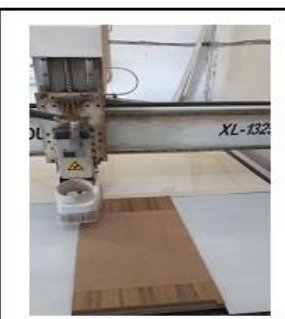

(1)

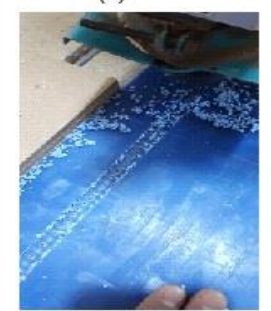

(4)

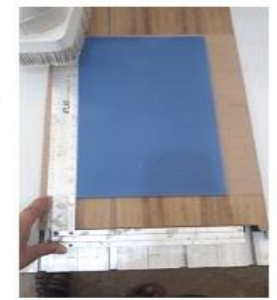

(2)

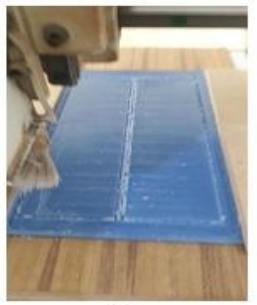

(5)

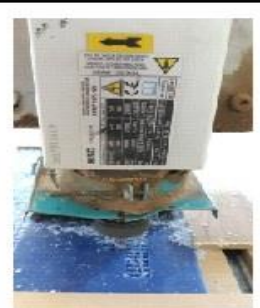

(3)

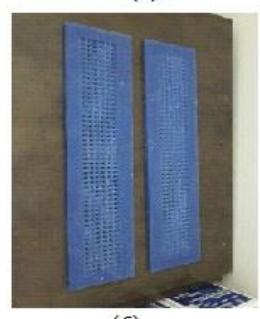

(6)
Figure 4. Steps of manufacture processing

\subsubsection{Mold preparation}

In this step, it had been assembled two half wax panels in form of one body and then trapped it between plastic or glass plates to get mold, as Figure 5.

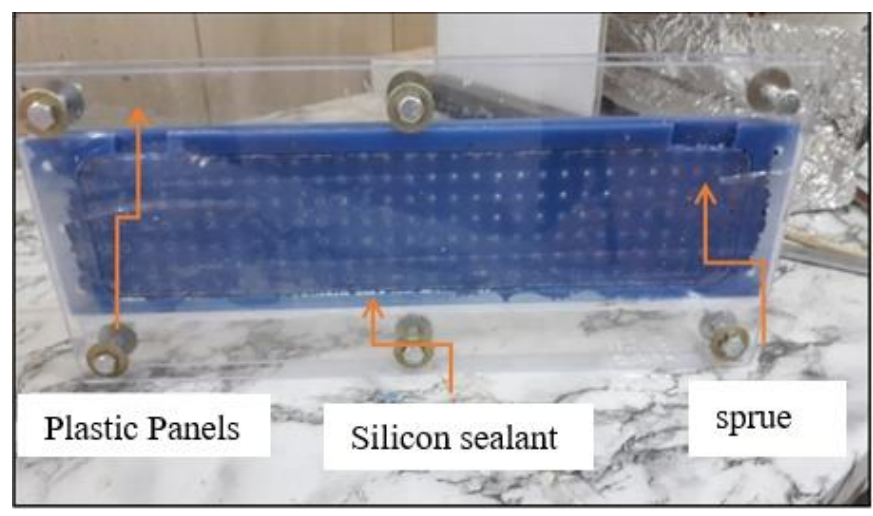

Figure 5. Mold for UPS casting

\subsubsection{Resin casting}

In this step, UPS resin with $1 \%$ hardener was poured into the mold, then putting the mold under vacuum nearly $9 \mathrm{KPa}$ at 5 min until casting finish, as Figure 6.

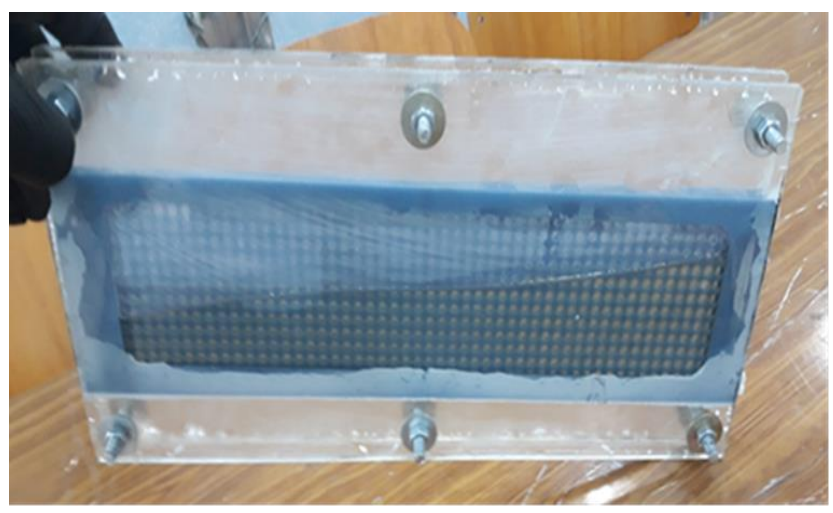

Figure 6. Casting UPS resin in mold

\subsubsection{Elimination step}

This step is the last step. In it, wax was eliminated by putting the casted UPS in boiling water path for nearly $30 \mathrm{~min}$ to get sandwich sphere structure (SSS), as Figure 7.

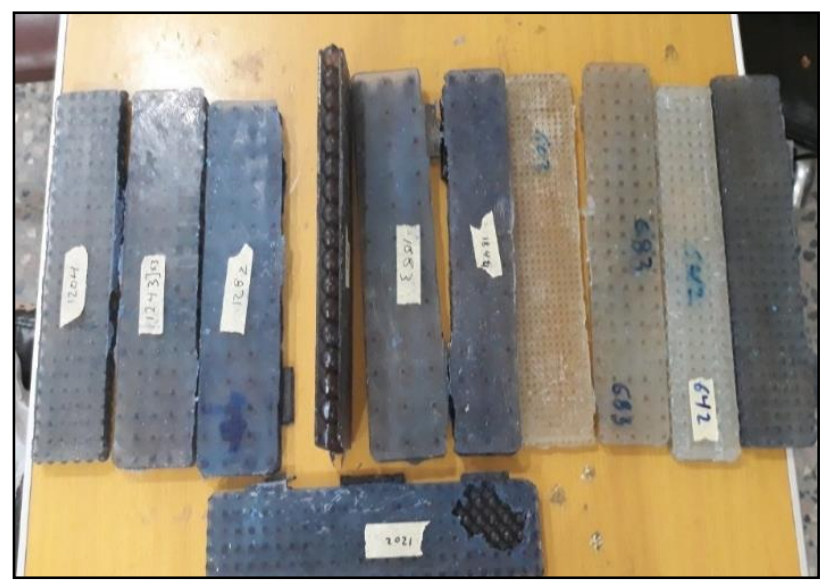

Figure 7. The sandwich sphere structure specimens

\subsection{Impact test}

By solid- pendulum impact tester, the energy absorbed at break "Uc" was founded to calculate specific impact energy with Joule per shape density unit. impact specimens are shown in Figure 8. It can be calculating impact strength Gc and fracture toughness Kc according to Eqns. (2) and (3) by ISO 179-1:200 standard.

$$
\begin{gathered}
G_{c}=\frac{U_{c}}{A} \\
\mathrm{~K}_{\mathrm{c}}=\sqrt{\mathrm{Gc} \mathrm{E}_{\mathrm{b}}}
\end{gathered}
$$

where,

Kc: Fracture toughness MPa.m $\mathrm{m}^{1 / 2}$

Gc: strength of Impact $\mathrm{J} / \mathrm{m}^{2}$

$\mathrm{U}_{\mathrm{c}}$ : Energy impact $\mathrm{J}$

$\mathrm{E}_{\mathrm{b}}$ : Modulus of elasticity Mpa 


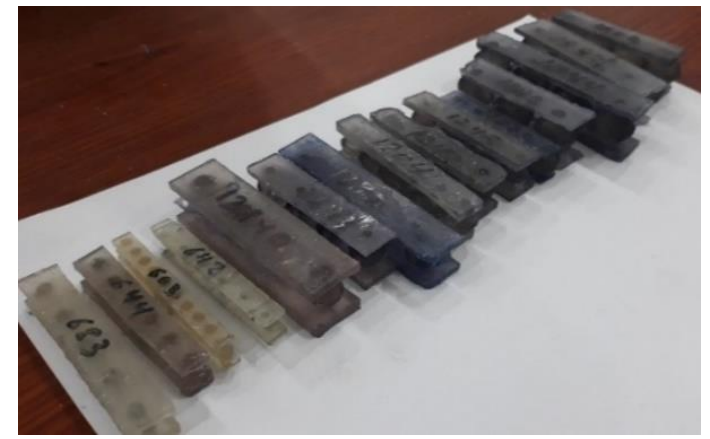

Figure 8. Impact specimens

\section{RESULTS AND DISCUSSION}

Unnotched specimens of sandwich sphere structure tested by impact instrument to find impact energy at break, and then calculated specific fracture toughness $[K c / w]$ according to Eqns. (2) and (3). The results are tabulated as Table 4 for all the designed models by Box-Behenkin method.

Table 4. Specific fracture toughness

\begin{tabular}{ccc}
\hline No & code & $\begin{array}{c}\mathbf{K c} / \mathbf{w} \\
\mathbf{M P a ~ m}^{\mathbf{0 . 5}} \mathbf{g}^{-\mathbf{1}}\end{array}$ \\
\hline 0 & UPS Block & 12.49 \\
1 & 642 & 50.96289 \\
2 & 603 & 19.48466 \\
3 & 683 & 26.60287 \\
4 & 644 & 23.51721 \\
5 & 1202 & 16.33604 \\
6 & 1282 & 5.124259 \\
7 & 1243 & 7.908311 \\
8 & 1243 & 7.544694 \\
9 & 1243 & 7.862164 \\
10 & 1204 & 10.02117 \\
11 & 1284 & 1.830693 \\
12 & 1842 & 3.045314 \\
13 & 1803 & 3.946808 \\
14 & 1883 & 2.547384 \\
15 & 1844 & 1.556015 \\
\hline
\end{tabular}

After RSM analysis, the data of specific fracture toughness has modeled in Eq. (4). Eq. (4) is a full quadradic model with confidence level equal $90 \%$. This model contains linear parametric $(\mathrm{D}, \mathrm{X}, \mathrm{K})$, square parametric $\left(\mathrm{D}^{2}, \mathrm{X}^{2}, \mathrm{~K}^{2}\right)$ and twoway interaction $\left(D^{*} \mathrm{X}, \mathrm{D}^{*} \mathrm{~K}, \mathrm{X}^{*} \mathrm{~K}\right)$. The coefficient of determination $\mathrm{R}^{2}$ for this model equals $90.33 \%$.

$$
\begin{gathered}
\frac{K c}{w}=151.2-40.1 \mathrm{k}+1.59 \mathrm{x}-10.78 \mathrm{D}+3.59 \mathrm{k} * \mathrm{k}- \\
0.190 \mathrm{x} * \mathrm{x}+0.234 \mathrm{D} * \mathrm{D}+0.189 \mathrm{k} * \mathrm{x}+1.082 \mathrm{k} * \mathrm{D}- \\
0.089 \mathrm{x} * \mathrm{D}
\end{gathered}
$$

According to ANOVA analysis, there are variables at $\mathrm{P}$ value less than or equal 0.1 whereas at greater than 0.1 . Table 5 shows significant and insignificant (denoted*) P-value. The insignificant terms are eliminated in the model presented above after maintaining hierarchy rules to get prediction model (Eq. (5)) that forecast the actual outcomes.

$$
\begin{gathered}
\frac{K c}{w}=80.8-4.82 \mathrm{k}+ \\
0.64 \mathrm{x}-7.50 \mathrm{D}+0.232 \mathrm{D} * \mathrm{D}- \\
0.089 \mathrm{x} * \mathrm{D}
\end{gathered}
$$

Table 5. Regression coefficients for specific fracture toughness

\begin{tabular}{ccc}
\hline Variable & F-value & P-value \\
\hline $\mathrm{K}$ & 3.86 & 0.107 \\
$\mathrm{X}$ & 0.49 & 0.516 \\
$\mathrm{D}$ & 31.17 & 0.003 \\
$\mathrm{~K} * \mathrm{~K}$ & 0.99 & $0.365^{*}$ \\
$\mathrm{X} * \mathrm{X}$ & 0.71 & $0.439^{*}$ \\
$\mathrm{D} * \mathrm{D}$ & 5.43 & 0.067 \\
$\mathrm{~K} * \mathrm{X}$ & 0.05 & $0.836^{*}$ \\
$\mathrm{~K} * \mathrm{D}$ & 3.5 & $0.12^{*}$ \\
$\mathrm{X}{ }^{*} \mathrm{D}$ & 0.38 & $0.566^{*}$ \\
\hline $\mathrm{R}^{2}$ & \multicolumn{3}{c}{$90.33 \%$} \\
\hline \multicolumn{4}{|}{}
\end{tabular}

Table 6 shows significant regression coefficients for specific fracture toughness after eliminating insignificant of Pvalue from Table 5 and return RSM analysis process.

Table 6. Regression coefficients for specific fracture toughness after eliminating insignificant terms

\begin{tabular}{ccc}
\hline Variable & F-value & P-value \\
\hline $\mathrm{K}$ & 3.35 & 0.101 \\
$\mathrm{X}$ & 0.42 & 0.532 \\
$\mathrm{D}$ & 27 & 0.001 \\
$\mathrm{D} * \mathrm{D}$ & 4.17 & 0.058 \\
$\mathrm{X}$ D & 0.33 & 0.581 \\
\hline $\mathrm{R}^{2}$ & \multicolumn{2}{c}{$79.9 \%$} \\
\hline
\end{tabular}

Figure 9 show main effects plot for specific fracture toughness, linearity effects between inputs and response has showed. D factor has highly effect on response with F-value equal 27 and greater value of response at $6 \mathrm{~mm}$, the relationship between diameter and response is direct proportionality. $\mathrm{K}$ factor has less effect than $\mathrm{D}$ factor with $\mathrm{F}$ value equal 3.35 with direct proportionality between $\mathrm{X}$ factor and response. $\mathrm{X}$ factor has low F-value so it's small effect on response has showed.

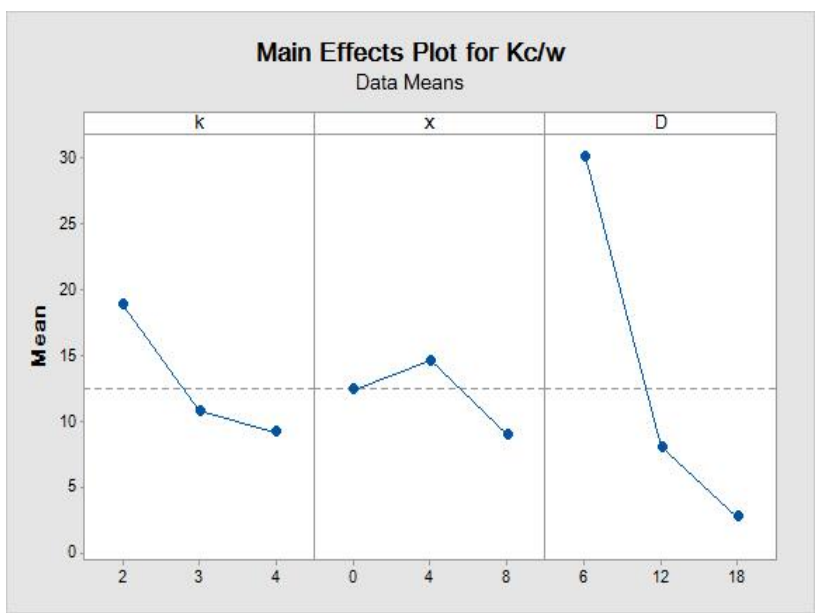

Figure 9. The main effects plot between specific fracture toughness and variables

Figure 10 shows the optimization of the values of $K c / w$ to find out the optimal input values based on the prediction model and denoted by Cur symbol, its values are $((D=6 \mathrm{~mm}),(X=8$ $\mathrm{mm})$ and $(\mathrm{K}=2 \mathrm{~mm}))$. These input optimal values have been investigated experimentally. Table 7 shows comparison between optimize value and practice value, there is $10 \%$ error between these values due to manufacturing condition. 


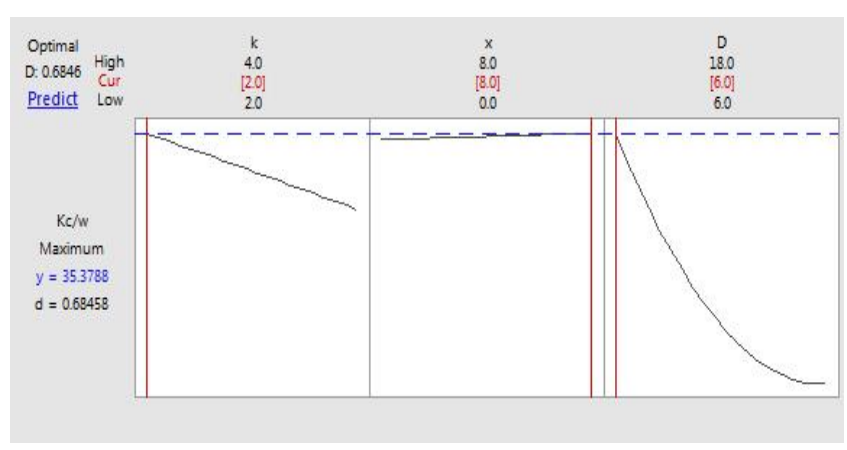

Figure 10. The optimal value for variables with specific fracture toughness

Table 7. Optimal and practice values of specific fracture toughness

\begin{tabular}{cccc}
\hline Code & $\begin{array}{c}\text { Optimal Value } \\
\text { MPa m }^{\mathbf{0 . 5}} \mathbf{g}^{-1}\end{array}$ & $\begin{array}{c}\text { Practice Value } \\
\text { MPa m } \mathbf{~ m}^{\mathbf{0 . 5}} \mathbf{g}^{-\mathbf{1}}\end{array}$ & Error \\
\hline 682 & 35.37 & 31.46 & $10 \%$ \\
\hline
\end{tabular}

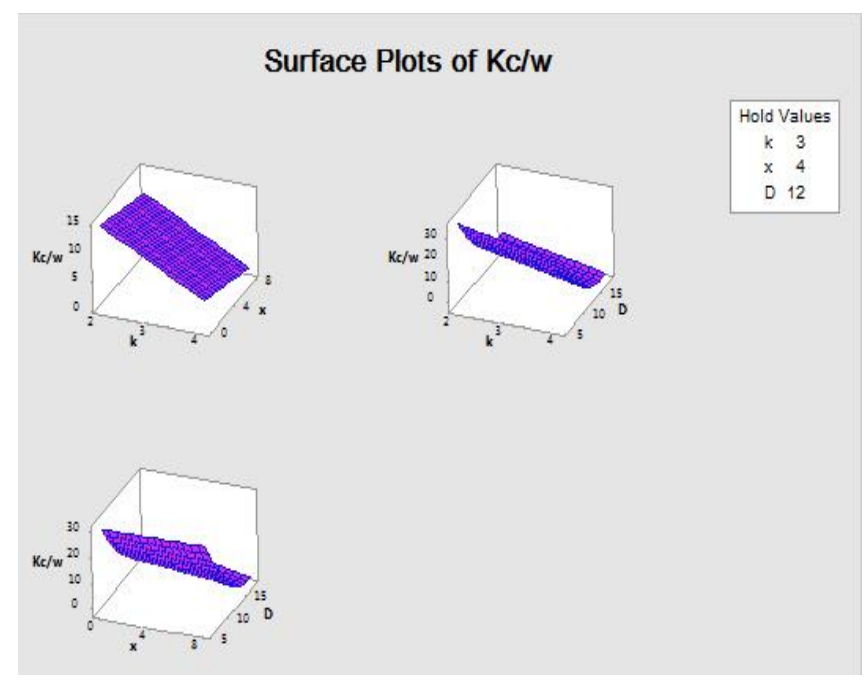

Figure 11. The plot of surface of specific fracture toughness with inputs

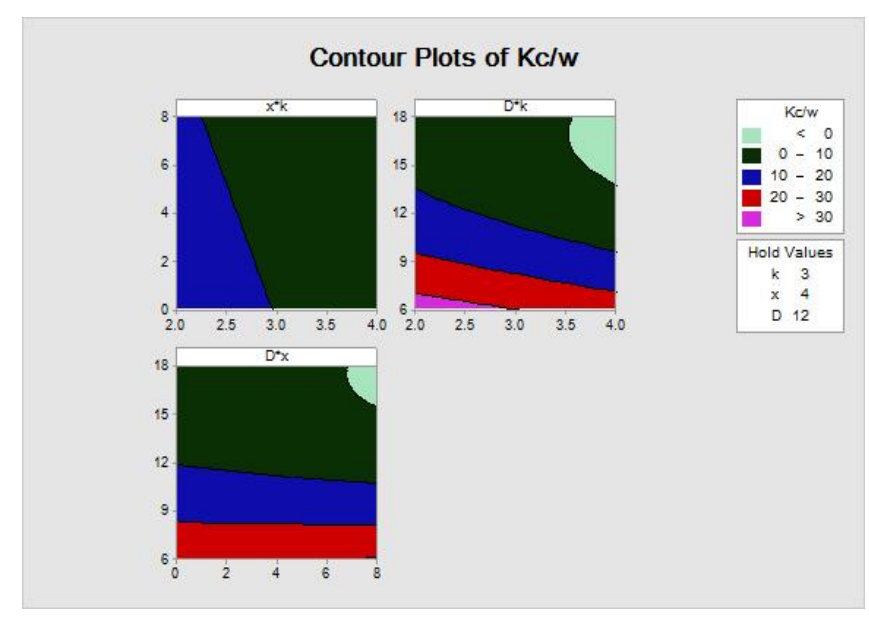

Figure 12. The plot of contour of specific fracture toughness response with inputs. (The direction of arrows indicates the increase of data values)

The combination effect of diameter (D), distance between spheres $(\mathrm{X})$ at and skin thickness $(\mathrm{K})$ at a middle value (constant level) of these variables has been viewed in Figure
11 and Figure 12 in surface (3-Dimension) and contour (2Dimension) format. It can be seen that higher specific fracture toughness response is achievable at the higher right area of contour plot of $\left(D^{*} \mathrm{~K}\right)$ and $\left(\mathrm{D}^{*} \mathrm{X}\right)$ whereas $\left(\mathrm{X}^{*} \mathrm{~K}\right)$ interaction have lower specific fracture toughness response than other interaction. The $\left(\mathrm{D}^{*} \mathrm{~K}\right)$ interaction indicates the decreasing of (K) factor led to improvement of specific fracture toughness if the factor (D) was less than $7 \mathrm{~mm}$. The $\left(D^{*} X\right)$ interaction indicates the increasing of $(\mathrm{X})$ factor led to improvement of specific fracture toughness if the factor (D) was less than $9 \mathrm{~mm}$.

\section{CONCLUSIONS}

1-The improvement percentage of specific fracture toughness is $307 \%$ for the specimen (642) as compare with monolithic sample

2-The maximum value of specific fracture toughness is 50.9 $\mathrm{J} / \mathrm{g}$ for the specimen (642) and optimal value is $35.37 \mathrm{~J} / \mathrm{g}$ for the specimen (682).

3-Good agreement between optimal and experimental results with not exceed error $10 \%$.

4-The main affected factor is sphere diameter (D) according to ANOVA analysis and then skin thickness $(\mathrm{K})$.

\section{ACKNOWLEDGMENT}

Thanks to all the co-authors and the team for the engineering materials collage in university of Babylon and for the work done. Thanks to Prof. Ahmad M. Shoushtari, cosuperviser of my Ph.D. thesis, for the support given to the corresponding author

\section{REFERENCES}

[1] Davies, G. (2003). Materials for Automobile Bodies. Butterworth-Heinemann. https://doi.org/10.1016/B9780-7506-5692-4.X5014-6

[2] Muhammad, N.S., Hambali, A., Rosidah, J., Widodo, W.S., Ahmad, M.N. (2017). A review of energy absorption of automotive bumper beam. International Journal of Applied Engineering Research, 12(2): 238245.

[3] Cheon, S.S., Lim, T.S., Lee, D.G. (1999). Impact energy absorption characteristics of glass fiber hybrid composites. Composite Structures, 46(3): 267-278. https://doi.org/10.1016/S0263-8223(99)00064-1

[4] Belingardi, G., Beyene, A.T., Koricho, E.G., Martorana, B. (2015). Alternative lightweight materials and component manufacturing technologies for vehicle frontal bumper beam. Composite Structures, 120: 483495. https://doi.org/10.1016/j.compstruct.2014.10.007

[5] Davoodi, M.M., Sapuan, S.M., Yunus, R. (2008). Conceptual design of a polymer composite automotive bumper energy absorber. Materials \& Design, 29(7): 1447-1452. https://doi.org/10.1016/j.matdes.2007.07.011

[6] Suddin, M.N., Salit, M.S., Ismail, N., Maleque, M.A., Zainuddin, S. (2005). Total design of polymer composite automotive bumper fascia. Suranaree J. Sci. Technol., 12(12): 39-45.

[7] Kumar, K.A., Boominathan, N., Akilan, D. (2014). 
Design and analysis of automobile bumper with the capacity of energy release. IOSR-JMCE, 11(2): 21-27. https://doi.org/10.9790/1684-11222127

[8] McCrum, N.G., Buckley, C.P., Bucknall, C.B. (1997). Principles of Polymer Engineering. 2nd edition. Oxford University Press.

[9] Andrews, M.D. (2012). Multi-layer composite armor and method. patent No. US8096223B1. https://patents.google.com/patent/US8096223B1/en?q= MULTILAYER+COMPOSITE+ARMOR+AND+MET HOD\&oq=MULTILAYER+COMPOSITE+ARMOR+ AND+METHOD, accessed on Jan. 28, 2020.

[10] Fu, Y., Zhou, J., Gao, X. (2013). Design and numerical simulation of a new sandwiched sphere structure for ballistic protection. International Journal of Impact Engineering, 58: 66-75. https://doi.org/10.1016/j.ijimpeng.2013.03.005

[11] Fu, Y., Zhou, J., Gao, X. (2014). Sandwiched hollow sphere structures: A study of ballistic impact behavior using numerical simulation. Journal of Mechanical Engineering Science, 228(12): 2068-2078. https://doi.org/10.1177/0954406213515857

[12] Pandyaraj, V., Rajadurai, A., Anand, G. (2018). Experimental investigation of compression strength in novel sandwich structure. Mater. Today Proc., 5(2): 8625-8630. https://doi.org/10.1016/j.matpr.2017.11.561

[13] Yu, T.X., Lam, S.W., Tao, X.M. (2004). Non-woven fabric reinforced cellular textile composites with

improved energy absorption capacity. Proceedings of the Fourth Asian-Australasian Conference on Composite Materials (ACCM 4), pp. 461-465. https://doi.org/10.1016/B978-1-85573-831-7.50080-8

[14] Yu, T.X., Tao, X.M., Xue, P. (2000). The energyabsorbing capacity of grid-domed textile composites. Composites Science and Technology, 60(5): 785-800. https://doi.org/10.1016/S0266-3538(99)00174-8

\section{NOMENCLATURE}

SSS

$\mathrm{D}$

$\mathrm{X}$

$\mathrm{K}$

RSM

DOE

L

b

d

$\mathrm{T}_{\text {wax panel }}$

$\mathrm{R}$

$\mathrm{Kc}$

$\mathrm{Gc}$

$\mathrm{U}_{\mathrm{c}}$

$\mathrm{E}_{\mathrm{b}}$ sphere sandwich structure

Diameter of sphere, $\mathrm{mm}$

Distance between spheres, $\mathrm{mm}$

Skin thickness, mm

Response surface methodology

Design of Experiments

Span Length of specimen, $\mathrm{mm}$

Width of specimen, $\mathrm{mm}$

Thickness of specimen, $\mathrm{mm}$

Thickness of wax plate, $\mathrm{mm}$

Radius of Sphere, mm

Fracture toughness, MPa.m ${ }^{1 / 2}$

strength of Impact, $\mathrm{J} / \mathrm{m}^{2}$

Energy impact, J

Modulus of elasticity, MPa 